\title{
Analisis Kelayakan Usaha Particle Board Sebagai Pemanfaatan Limbah Kayu (Studi Kasus: CV. Riau Pallet)
}

\author{
Isum Kusumanto ${ }^{1}$, Nofia Putri Sundari ${ }^{2}$ \\ 1,2 Jurusan Teknik Industri, Fakultas Sains dan Teknologi, UIN Sultan Syarif Kasim Riau \\ Jl. HR. Soebrantas No. 155 Simpang Baru, Panam, Pekanbaru, 28293 \\ Email: ismu_uin@yahoo.co.id, nputrisundari@yahoo.com
}

\begin{abstract}
Abstrak
CV Riau Pallet merupakan sebuah perusahaan manufaktur yang bergerak dalam pengolahan hasil kayu hutan menjadi pallet dengan sistem produksinya adalah Make To Order. Industri pengolahan kayu seperti CV. Riau Pallet tidak hanya menghasilkan pallet tetapi juga akan menghasilkan limbah berupa sisa serbuk kayu yang tidak dapat digunakan lagi untuk membuat pallet. Sisa serbuk kayu pallet ini pada CV. Riau Pallet hanya ditumpuk pada tempat pembuangan,dan dibakar. Berdasarkan permasalahan-permasalahan tersebut CV. Riau Pallet ingin mendirikan usaha untuk pemanfaatan limbah serbuk kayu yang dijadikan papan partikel (Particle board). Papan partikel adalah produk panil yang dihasilkan dengan menempatkan partikel-partikel kayu dan sekaligus mengikatnya dengan suatu perekat. Penelitian ini bertujuan untuk menganalisis tingkat kelayakan produksi particle board di CV. Riau Pallet berdasarkan aspek pemasaran, aspek teknis, aspek legal dan lingkungan, aspek manajemen sumber daya manusia dan aspek finansial. Dari hasil pengolahan data, Aspek pemasaran yang didapat dari hasil kuisioner yang disebar ke 27 orang pemilik industri perabot dari kayu, yang didominasi oleh laki-laki dan berumur lebih dari 25 tahun beradasarkan pernyataan-pernyataan yang diberikan berada di atas $67 \%$ yang berarti pernyataan-pernayataan yang diberikan kepada setiap responden, responden menyetujuinya. Dari segi aspek teknis produksi setiap 1 particle board ukuran standar dibutuhkan $31.974 \mathrm{~cm}^{3}$ serbuk kayu dan $3202 \mathrm{~cm}^{3}$ resin atau setara dengan 3,2 liter resin, dengan hasil produksi berdasarkan limbah yang ada setiap bulannya rata-rata bisa menghasilkan 470 lembar papan. Aspek legal dan lingkungan tidak lagi di butuhkan pengurusan ulang SIUP dan surat tanda daftar Industri karena jenis usaha yang terdaftar sama. Berdasarkan aspek manajemen, produksi particle board tidak membutuhkan pendidikan formal atau pengetahuan khusus tetapi lebih memerlukan ketrampilan dan ketekunan. Tenaga kerja yang di butuhkan dalam memproduksi pupuk kompos sebanyak 9 orang. Berdasarkan aspek finansial, dengan kebutuhan investasi awal sebesar Rp 548.850.000,- dan diperoleh nilai Net Present Value (NPV) sebesar Rp 586.551.152,-, merupakan nilai yang positif. Nilai Internal Rate of Return (IRR) sebesar 40\%, nilai ini lebih besar dari MARR 7,1\%. Payback period diperoleh dengan metode trial and error yaitu dalam waktu 1 tahun 1 bulan
\end{abstract}

Kata Kunci: Analisis Kelayakan Usaha, Internal Rate Of Return, Net Present Value, Payback Period, Particle Board

\section{Pendahuluan}

Seiring dengan perkembangan dan kemajuan teknologi, perkembangan dunia usaha mengalami persaingan yang begitu ketat. Agar dapat memenangkan persaingan tersebut perusahaan menggunakan berbagai cara diantaranya yaitu mengoptimalkan sumber daya, baik sumber daya manusia, proses produksi hingga kualitas produk untuk dapat meningkatkan produktivitas. Berbicara mengenai produktivitas maka, perlu diupayakan proses produksi yang mampu memberikan kontribusi penuh terhadap kegiatankegiatan produktif yang berkaitan dengan nilai tambah.

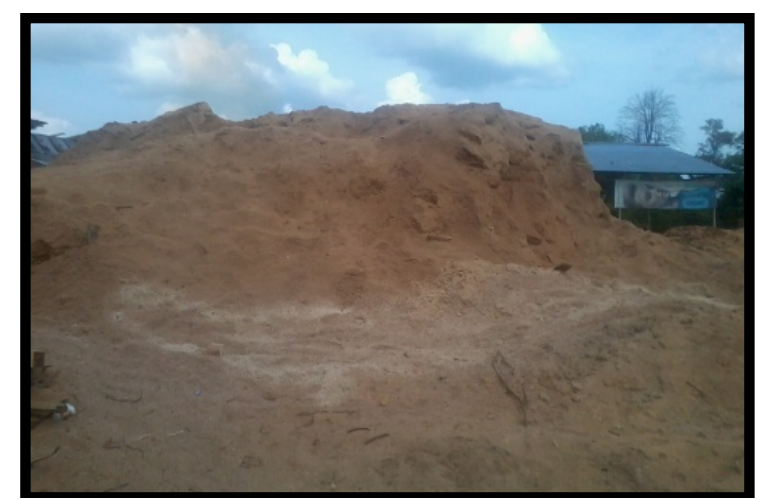

Gambar 1.1 Penumpukan Serbuk Kayu di Tempat Pembuangan (Sumber : CV. Riau Pallet) 
Industri pengolahan kayu seperti CV. Riau Pallet tidak hanya menghasilkan pallet tetapi juga akan menghasilkan limbah berupa sisa serbuk kayu yang tidak dapat digunakan lagi untuk membuat pallet. Sisa serbuk kayu pallet ini pada CV. Riau Pallet hanya ditumpuk pada tempat pembuangan, lama kelamaan limbah serbuk kayu tadi akan menumpuk akhirnya akan dibakar. Kepulan asap dari pembakaran serbuk kayu tersebut akan masuk ke area lantai produksi karena tempat pembuangan yang tidak jauh dari lantai produksi, hal ini tentu saja akan berpengaruh pada produktivitas pekerja. Berikut adalah data jumlah limbah serbuk kayu dari pengolahan pembuatan pallet per bulan:

Tabel 1.1 Data Jumlah Limbah Serbuk Kayu pada CV. Riau Pallet

\begin{tabular}{|l|l|c|c|l|}
\hline No & Bulan & Tahun & $\begin{array}{l}\text { Jumlah } \\
\text { Produksi } \\
\text { Pallet } \\
\text { (Buah) }\end{array}$ & $\begin{array}{l}\text { Jumlah } \\
\text { Scrap } \\
\mathbf{( m}^{\mathbf{3}} \mathbf{)}\end{array}$ \\
\hline 1 & November & 2014 & 9521 & 20,94 \\
\hline 2 & Desember & 2014 & 9834 & 21,78 \\
\hline 3 & Januari & 2015 & 10341 & 22,40 \\
\hline 4 & Febuari & 2015 & 9468 & 20,42 \\
\hline 5 & Maret & 2015 & 9628 & 21,08 \\
\hline 6 & April & 2015 & 10543 & 22,64 \\
\hline 7 & Mei & 2015 & 10637 & 22,90 \\
\hline 8 & Juni & 2015 & 10243 & 21,70 \\
\hline 9 & Juli & 2015 & 9343 & 20,40 \\
\hline 10 & Agustus & 2015 & 10123 & 22,20 \\
\hline 11 & September & 2015 & 9501 & 20,78 \\
\hline 12 & Oktober & 2015 & 9536 & 20,98 \\
\hline \multicolumn{2}{|l|}{ Rata-rata } & $\mathbf{9 8 9 3 , 1 7}$ & $\mathbf{2 1 , 5 2}$ \\
\hline
\end{tabular}

(Sumber : CV. Riau Pallet, 2015)

Berdasarkan Tabel 1.1 dapat dilihat bahwa jumlah serbuk kayu yang dihasilkan dari pengolahan pembuatan Pallet sangat banyak setiap bulannya, maka berdasarkan jumlah limbah serbuk kayu yang sangat banyak maka dilakukan pengolahan terhadap limbah serbuk kayu tersebut untuk dijadikan produk sehingga dapat dimanfaatkan.

Berdasarkan permasalahan-permasalahan tersebut CV. Riau Pallet ingin mendirikan usaha untuk pemanfaatan limbah serbuk kayu yang dijadikan papan partikel (Particle board). Papan partikel adalah produk panil yang dihasilkan dengan menempatkan partikel-partikel kayu dan sekaligus mengikatnya dengan suatu perekat. Papan partikel merupakan lembaran hail pengempaan panas campuran partikel kayu atau bahan berligno selulosa lainnya, dengan perekat organik dan bahan lainnya (Syafrudin dkk, 2012).

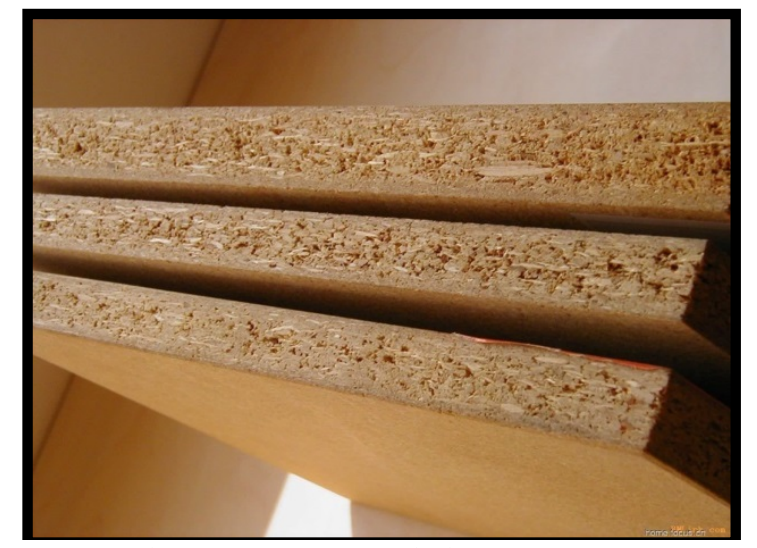

Gambar 1.3 Papan Partikel (Particle Board)

\section{Tinjauan Pustaka}

\section{Papan Partikel}

Papan partikel merupakan produk panel yang dihasilkan dengan memanfaatkan partikel-partikel kayu sekaligus mengikatnya dengan suatu perekat. Tipe-tipe papan partikel yang jumlahnya cukup banyak sangat berbeda dalam hal ukuran dan bentuk partikel, jumlah resin yang digunakan dan kerapatan panel yang dihasilkan. Sifat-sifat dan kegunaan potensial papan berbeda dengan peubahpeubah ini (Haygreen dan Bowyer, 1996 dalam Irfani, 2011).

Maloney (1993) dalam Irfani (2011) menyatakan bahwa papan partikel merupakan salah satu jenis produk komposit atau panel kayu yang terbuat dari partikelpartikel kayu atau bahan berlignoselulosa lainnya yang diikat dengan perekat sintesis atau bahan pengikat lainnya dan dikempa panas. Jika dibandingkan dengan kayu asalnya, papan partikel mempunyai beberapa kelebihan antara lain papan partikel bebas cacat seperti mata kayu, pecah, maupun retak, ukuran dan kerapatan papan partikel dapat disesuaikan dengan kebutuhan, tebal dan kerapatan papan partikel seragam serta mudah dikerjakan, mempunyai sifat isotropis, serta sifat dan kualitasnya dapat diatur.

Proses produksi yang dilakukan pada pemanfaatan limbah kayu sebagai bahan dasar papan partikel adalah sebagai berikut (Chayandri, 2007) serbuk kayu dibersihkan dari kotoran yang mungkin ada seperti tanah, kerikil. Paku dan lain - lainnya. Kemudian dikeringkan untuk mengurangi kadar air serbuk kayu. Setelah bersih kemudian kita buat bubur kayu dan adhesive sebagai matriks. Kemudian dari bubur kayu-adhesive yang sudah jadi di cetak dan dipress sesuai ukuran yang direncanakan. Dengan proses pencetakan kurang lebih 6 menit maka jadilah papan partikel yang masih dalam keadaan kasar.

\section{Studi Kelayakan Bisnis}

Kelayakan artinya penelitian yang dilakukan secara mendalam untuk menentukan apakah usaha yang akan dijalankan akan memberikan manfaat yang lebih besar dibandingkan dengan biaya yang akan dikeluarkan. Sedangkan pengertian bisnis adalah usaha yang dijalankan yang tujuan utamanya untuk memperoleh 
keuntungan. Keuntungan yang dimaksud dalam perusahaan bisnis ialah keuntungan finansial.

Menurut Fahmi (2014) Studi kelayakan bisnis adalah suatu kajian ilmu yang menilai pengerjaan suatu bisnis untuk dilihat layak atau tidak layak (feasible or infeasible) dilaksanakan dengan menempatkan ukuran-ukuran baik kuantitatif dan kualitatif yang akhirnya terangkum dalam sebuah rekomendasi.

Sedangkan menurut Husein Umar (2005) dalam Yori (2013) Studi Kelayakan bisnis merupakan penelitian terhadap rencana bisnis yang tidak hanya menganalisis layak atau tidak layaknya bisnis dibangun, tetapi juga saaat dioperasionalkan secara rutin dalam rangka pencapaian keuntungan yang maksimal untuk waktu yang tidak ditentukan, misalnya rencana peluncuran produk baru.

Untuk menentukan layak atau tidaknya suatu usaha dapat dilihat dari berbagai aspek. Setiap aspek untuk bisa dikatakan layak harus memiliki suatu standar nilai tertentu, namun keputusan penilaian tidak hanya dilakukan pada satu aspek saja. Penilaian untuk menentukan kelayakan harus didasarkan kepada seluruh aspek yang akan dinilai nantinya. Ukuran kelayakan masing-masing jenis usaha sangat berbeda, misalnya antara usaha jasa dan usaha non jasa, seperti pendirian hotel dengan usaha pembukaan perkebunan kelapa sawit atau usaha peternakan dengan pendidikan. Akan tetapi, aspek-aspek yang digunakan untuk menyatakan layak atau tidaknya adalah sama sekalipun jenis usahanya berbeda (Fauzi,2012).

\section{Tujuan Studi Kelayakan Bisnis}

Menurut Kasmir dan Jakfar (2003) dalam Fauzi (2012), ada lima tujuan mengapa sebelum suatu usaha atau proyek dijalankan perlu dilakukan studi kelayakan yaitu:

\section{Menghindari Resiko Kerugian}

Karena dimasa yang akan datang ada semacam kondisi ketidakpastian. Kondisi ini ada yang dapat diramalkan akan terjadi atau memang dengan sendirinya terjadi tanpa diramalkan. Dalam hal ini fungsi studi kelayakan adalah untuk meminimalkan resiko yang dapat kita kendalikan maupun yang tidak dapat kita kendalikan.

\section{Memudahkan Perencanaan}

Jika kita sudah dapat meramalkan apa yang akan terjadi dimasa yang akan datang, maka akan mempermudah kita dalam melakukan perencanaan dan apa saja hal-hal yang perlu direncanakan. Perencanaan meliputi beberapa jumlah dana yang diperlukan, kapan usaha atau proyek akan dibangun, siapa saja yang akan melaksanakannya, bagaimana cara menjalankannya, berapa besar keuntungan yang akan diperoleh serta bagaimana mengawasinya jika terjadi penyimpangan.

\section{Memudahkan Pelaksanaan Pekerjaan}

Dengan adanya berbagai rencana yang sudah disusun akan sangat memudahkan pelaksanaan bisnis. Para pelaksana yang mengerjakan bisnis tersebut telah memiliki pedoman yang harus diikuti. Kemudian pengerjaan usaha dapat dilaksanakan secara sistematika, sehingga tepat sasaran dan sesuai dengan rencana yang sudah disusun. Rencana yang sudah disusun dijadikan acuan dalam mengerjakan setiap tahap yang sudah direncanakan.

\section{Memudahkan Pengawasan}

Dengan telah dilaksanakan suatu usaha atau proyek sesuai dengan rencana yang sudah disusun, maka akan mempermudah perusahaan untuk melakukan pengawasan terhadap jalannya usaha. Pengawasan ini perlu dilakukan agar pelaksanaan usaha tidak melenceng dari rencana yang telah disusun.

\section{Mempermudah Pengendalian}

Apabila dalam pelaksanaan pekerjaan telah dilakukan pengawasan maka jika terjadi suatu penyimpangan akan lebih mudah terdeteksi, sehingga akan dapat dilakukan pengendalian atas penyimpangan tersebut. Tujuan pengendalian adalah untuk mengendalikan pelaksanaan pekerjaan tidak melenceng dari rel yang sesungguhnya, sehingga pada akhirnya tujuan perusahaan tercapai.

\section{Tahapan Studi Kelayakan Bisnis}

Dalam melaksanakan studi kelayakan bisnis, ada beberapa tahapan yang hendaknya dikerjakan. Tahapantahapan tersebut secara umum adalah sebagai berikut (Fauzi, 2012):

\section{Penemuan Ide}

Produk yang akan dibuat haruslah berpotensi untuk laku dijual dan menguntungkan. Jika terdapat ide lebih dari satu, maka yang dipilih oleh pengambil keputusan biasanya tergantung pada pada faktor kesesuaian dengan ide pengambil keputusan tersebut, faktor dimana pengmabil keputusan akan mampu melibatkan diri dalam hal-hal yang sifatnya teknis dan keyakinan akan kemampuan proyek untuk mengahsilkan laba.

\section{Tahap Penelitian}

Setelah ide proyek dipilih, selanjutnya diakukan penelitian yang lebih mendalam dengan memakai metode ilmiah. Dimulai dengan mengumpulkan data, lalu mengolah data berdasarkan teori-teori yang relevan, menganalisis hasil pengolahan data dengan alat-alat analisis yang sesuai, menyimpulkan hasil sampai pada pekerjaan membuat laporan hasil penelitian tersebut.

\section{Tahap Evaluasi}

Evaluasi berarti membandingkan sesuatu dengan satu atau lebih standar atau kriteria. Hal yang dibandingkan dalam evaluasi bisinis ialah seluruh ongkos yang akan ditimbulkan oleh usulan bisnis serta manfaat atau benefit yang diperkirakan akan diperoleh

\section{Tahap Pengurutan Usulan yang Layak}

Jika terdapat lebih dari satu usulan rencana bisnis yang dianggap layak dan terdapat keterbatasan-keterbatasan yang dimiliki oleh manajemen untuk merealisasikan semua rencana bisnis tersebut, misalnya keterbatasan dana, maka perlu dilakukan pemilihan rencana bisnis 
yang dianggap paling penting direalisasikan. Sudah tentu yang diprioritaskan adalah rencana bisnis yang mempunyai skor tertinggi jika dibandingkan dengan uullan yang lain berdasarkan kriteria-kriteria penilaian yang telah ditentukan.

\section{Tahap Rencana Pelaksanaan}

Setelah rencana bisnis dipilih untuk direalisasikan, perlu dibuat rencana kerja pelaksanaan pembangunan proyek. Mulai daari menentukan jenis pekerjaan, waktu yang dibutuhkan untuk tiap jenis pekerjaan, jumlah dan kualifikasi tenaga pelaksana, ketersediaan dana dan sumber daya yang lain, kesiapan manajemen dan lainlain.

\section{Tahap Pelaksanaan}

Setelah semua persiapan yang harus dikerjakan selesai disiapkan, tahap berikutnya adalah merealisasikan pembangunan proyek tersebut. Kegiatan ini membutuhkan manajemen proyek. Jika proyek telah selesai dikerjakan, selanjutnya menjalankan operasional bisnis ini secara rutin.

\section{Aspek-aspek dalam Penilaian Kelayakan}

Dalam melakukan studi kelayakan melalui tahaptahap yang telah ditentukan, hendaknya dilakukan secara benar. Kemudian setiap tahapan memiliki berbagai aspek yang harus diteliti, diukur dan dinilai sesuai dengan ketentuan yang telah ditentukan.

\section{Aspek Pemasaran}

Faktor-faktor yang perlu diperhatikan dan ditelaah dalam aspek pemasaran adalah (Nurmalina dalam Irfani, 2011): 1. Permintaan, baik secara total atau diperinci menurut daerah, jenis konsumen, perusahaan besar pemakai. Di sini juga perlu diperkirakan tentang proyeksi permintaan tersebut.

2. Penawaran, baik yang berasal dari dalam negeri, maupun yang berasal dari impor. Bagaimana perkembangannya di masa lalu dan bagaimana perkiraan di masa yang akan datang. Faktor-faktor yang mempengaruhi penawaran ini seperti jenis barang yang bisa menyaingi, kebijakan dari pemerintah dan sebagainya perlu diperhatikan.

3. Harga, dilakukan perbandingan dengan barangbarang impor dan produksi dalam negeri lainnya. Apakah ada kecenderungan perubahan harga dan bagaimana polanya.

4. Program pemasaran, mencakup strategi pemasaran yang akan dipergunakan bauran pemasaran (marketing mix). Identifikasi siklus kehidupan produk (product life cycle), pada tahap apa produk akan dibuat.

5. Perkiraan penjualan yang bisa dicapai perusahaan, market share yang bisa dikuasai perusahaan.

Kekuatan analisis pemasaran dilihat pada kemampuan memahami konidsi pasar secara lebih realistis dan mengaplikasikannya secara aplikatif yang semua ini teraplikasi pada penciptaan produk yang memiliki nilai saing di pasar. Dan salah satu bagian penting dari pemasaran adalah keberanian dalam mengambil keputusan ketika keputusan tersebut diputuskan.

\section{Marketing Mix Strategy}

Strategi bauran pemasaran terbagi dua menurut (Fauzi, 2012) yaitu:

\section{Strategi Bauran Pemasaran Produk Barang}

Pemasaran produk barang, manajemen pemasaran akan dipecah atas 4 (empat) kebijakan pemasaran yaitu:

\section{a. Strategi Produk}

Pihak perusahaan terlebih dahulu harus mendefinisikan, memilih dan mendesain suatu produk disesuaikan dengan kebutuhan dan keinginan konsumen yang akan dilayaninya, agar investasi yang ditanam dapat berhasil dengan baik. Untuk produk barang, misalnya dalam bentuk seperti mutu, ciri dan desain. Mutu produk meunjukkan kemampuan sebuah produk untuk menjalankan fungsinya, ciri produk merupakan sarana kompetitif untuk membedakan produk perusahaan dengan produk pesaing, sedangkan desain dapat menyumbangkan kegunaan atau manfaat produk serta coraknya.

\section{b. Strategi Harga}

Harga adalah sejumlah uang yang diserahkan dalam pertukaran untuk mendapatkan suatu barang atau jasa. Penetuan harga sangat penting diperhatikan, mengingat harga merupakan salah satu penyebab laku tidaknya barang produk yang ditawarkan. Langkah-langkah yang perlu ditempuh dalam menetapkan harga yang tepat terhadap suatu produk adalah (Kasmir \& Jakfar, 2003 dalam Fauzi, 2012):

1) Menentukan tujuan penetapan harga

2) Memperkirakan permintaan, biaya dan laba

3) Memilih strategi harga untuk membantu menentukan harga dasar

4) Menyesuaikan harga dasar dengan taktik penetapan harga

Besarnya harga yang harus dipasang tentu disesuaikan dengan tujuan

penentuan harga. Ada tiga strategi dasar dalam penetapan harga, yaitu (Kasmir \& Jakfar, 2003 dalam Fauzi, 2012):

1) Skimming Pricing, yaitu harga awal produk yang ditetapkan setinggitingginya dengan tujuan bahwa produk memiliki kualitas tinggi.

2) Penetration Pricing, yaitu dengan menetapkan harga yang serendah mungkin dengan tujuan untuk menguasai pasar.

3) Status quo Pricing, yaitu penetapan harga yang ditetapkan disesuaikan dengan harga yang ditetapkan pesaing.

\section{c. Strategi Lokasi dan Distribusi}

Penetapan lokasi dan distribusi beserta saran dan prasarana pendukung menjadi sangat penting, hal ini disebabkan agar konsumen mudah menjangkau lokasi. Begitu pula harus memberikan rasa yang nyaman dan aman kepada seluruh konsumennya. Hal-hal yang perlu diperhatikan dalm pemilihan dan penentuan lokasi adalah dengan pertimbangan sebagai berikut:

1) Dekat dengan kawasan industri 
2) Dekat dengan lokasi perkantoran

3) Dekat dengan lokasi pasar

4) Dekat dengan pusat pemerintahan

5) Dekat dengan lokasi perumahan atau masyarakat

6) Mempertimbangkan jumlah pesaing yang ada di suatu lokasi

7) Sarana dan prasarana (jalan, listrik dan lain-lain)

d. Strategi Promosi

Promosi merupakan sarana yang paling ampuh untuk menarik dan mempertahankan konsumen. Salah satu tujuan promosi perusahaan adalah menginformasikan segala jenis produk yang ditawarkan dan berusaha menarik calon konsumen. Paling tidak ada empat macam sarana promosi yang dapat digunakan oleh perusahaan dalm mempromosikan produk dan jasa:

1) Periklanan (advertising)

Pengunaan promosi dengan iklan dapat dilakukan dengan berbagai media seperti billboard di jalan-jalan strategis, televise, koran, majalah dan media lainnya. Pertimbangan penggunann media yang akan dipakai untuk pemasangan iklan di suatu media, antara lain:

a) Jangkauan media yang akan digunakan

b) Sasaran atau konsumen yang akan dituju

c) Besarnya biaya yang akan dikeluarkan

2) Promosi Penjualan (Sales Promotion)

Promosi penjualan dilakukan untuk menarik pelanggan untuk segera membeli barang atau jasa yang ditawarkan. Promosi penjualan dapat dilakukan melalui :

a) Pemberian harga khusus atau potongan harga (discount) untuk produk tertentu

b) Pemberian undian kepada setiap pelanggan yang membeli dalam jumlah tertentu

c) Pemberian cenderamata kepada konsumen yang loyal, dan lain sebagainya.

e. publicity

Publisitas merupakan kegiatan promosi untuk memancing konsumen melalui kegiatan seperti pameran, bakti sosial serta kegiatan lain. Kegiatan publitas dapat meningkatkan pamor perusahaan di mata konsumennya.

f. Penjualan pribadi (Personal Selling)

Dalam dunia bisnis penjualan pribadi secara umum dilakukan oleh salesman dan salesgirl. Bagi sebagian perusahaan personal selling dilakukan oleh petugas customer service atau service assistence.

\section{Strategi Bauran Pemasaran Produk Jasa}

Bauran pemasaran untuk produk jasa lebih luas daripada bauran produk barang. Untuk jasa, baurannya dapat diperluas lagi dengan menambah tiga elemen, yaitu elemen orang (people), bukti fisik dan proses jasa itu sendiri (process).

a. Orang (people)

Yang dimaksud orang disini ialah semua partisipan yang memainkan penyajian jasa selama proses dan konsumsi jasa berlansung, oleh karenanya dapat mempengaruhi perpsepsi pembeli. Yang dimaksud dengan partisipan ini antara lain adalah staf perusahaan, konsumen dan lainlain.

\section{b. Bukti Fisik}

Yang dimaksud bukti fisik ialah suatu lingkungan dimana jasa disampaikan dan dimana perusahaan dan konsumennya berinteraksi, dan setiap komponen tangible memfasilitasi penampilan atau komunikasi jasa tersebut.

\section{c. Proses Jasa}

Proses ini mencerminkan bagaimana semua bauran pemasaran jasa dikoordinasikan untuk menjamin kualitas dan konsistensi jasa yang diberikan kepada konsumen.

\section{Metode Penelitian}

Penelitian ini akan dilakukan dengan tahapan sebagai berikut :

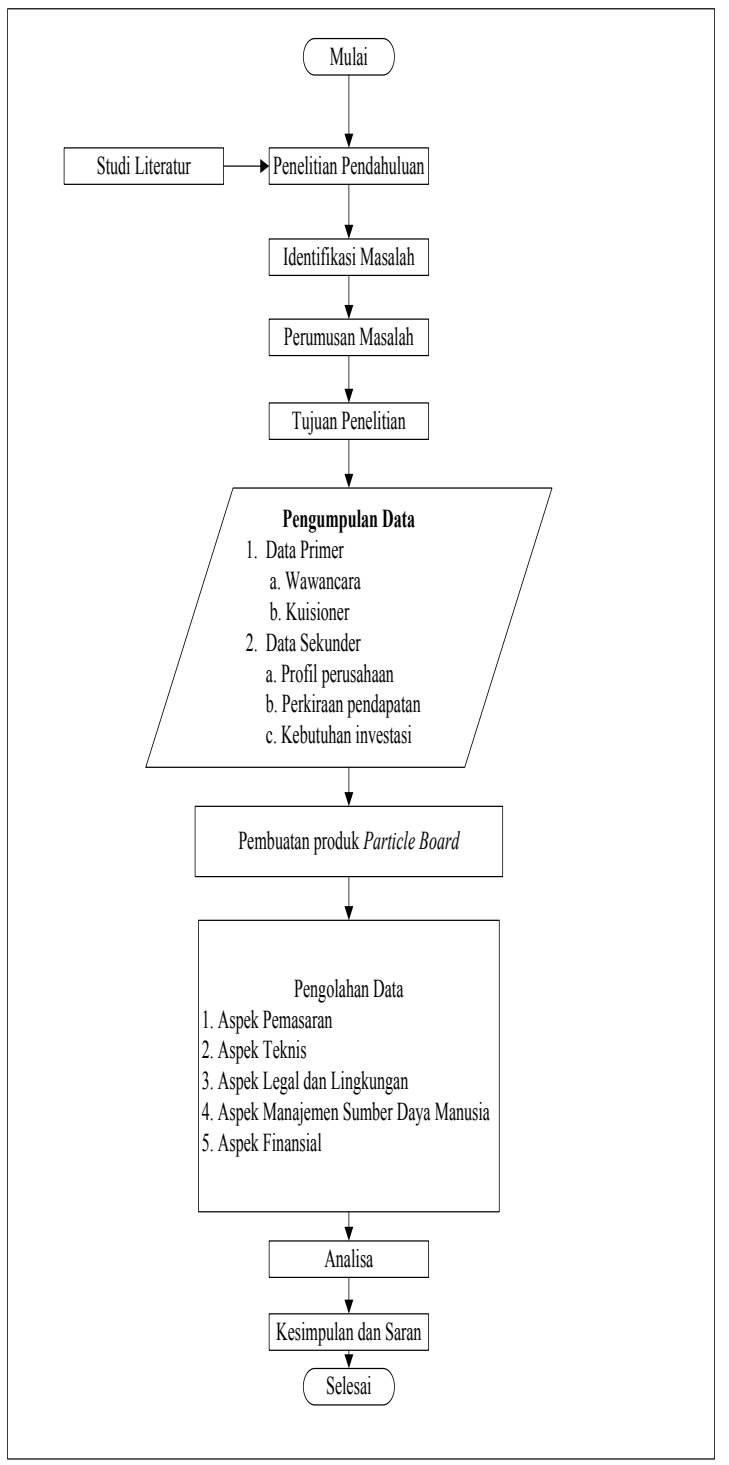

Gambar 3.1 Flowchart Metode Penelitian 


\section{Hasil dan Pembahasan}

\section{Aspek Pemasaran}

Hasil kuisioner yang sudah diolah pada software SPSS 16.0 yang menunujukan bahwa hasil yang idapat diatas $68 \%$ yaitu termasuk kedalam kategori setuju. Berarti dari13 pernyataan para responden setuju dengan pernyataan-pernyatan yang diberikan.

\section{Aspek Teknis}

Hal yang diperhatikan dalam aspek teknis adalah perancangan produk, berikut merupakan OPC atau peta proses operasi yang merupakan suatu diagram yang menggambarkan langkah-langkah yang akan dialami oleh bahan baku.

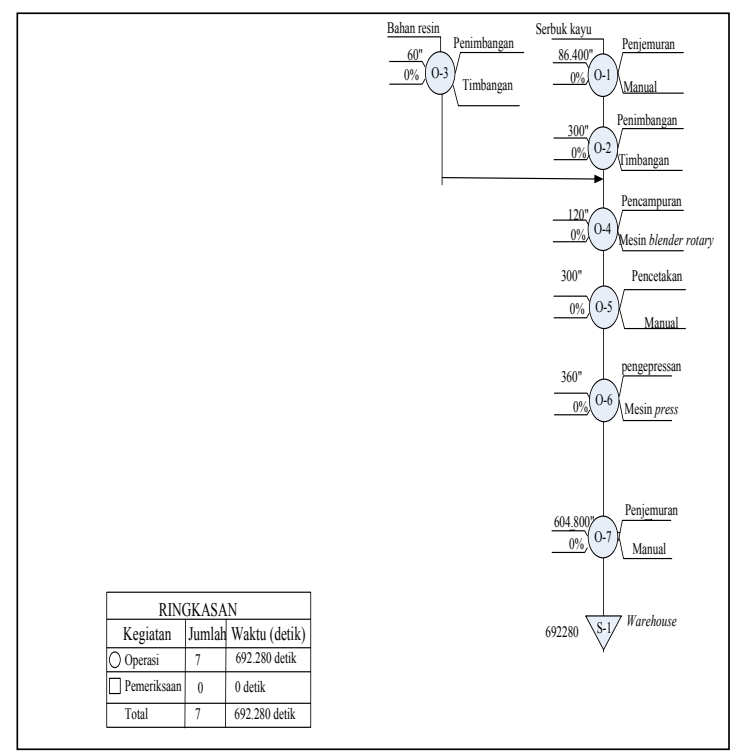

Gambar 4.6 Peta Proses Operasi Produksi Particle Board

Untuk menentukan perencanaan kapasitas produksi diperlukan kebutuhan bahan baku tiap bulanya agar dapat diketahui jumlah kapasitas produksi setiap bulannya. Untuk setiap pembuatan 1 papan partikel ukuran standar yakni $122 \times 224 \times 1,8 \mathrm{~cm}$ dibutuhkan $31.974 \mathrm{~cm}^{3}$ serbuk kayu dan $3202 \mathrm{~cm}^{3}$ resin atau setara dengan 3,2 liter resin.

\section{Aspek Legal dan Lingkungan}

Usaha papan partikel adalah usaha yang akan dibuka di CV. Riau Pallet, yang tentunya sudah memiliki izin dari pemerintah daerah Kabupaten Kampar sehingga usaha ini menggunakan limbah-limbah serbuk kayu yang tidak digunkan lagi dari sisa penggergajian kayu pallet. Dalam suatu usaha perdagangan perizinan/legalitas yang harus dimiliki antara lain Surat Izin Usaha Perdagangan (SIUP), surat tanda daftar perusahaan perorangan .
CV. Riau Pallet juga memiliki surat-surat lainnya yang berhubungan dengan kelegalan pendirian usaha ini, pada awalnya surat-surat kelegalan tersebut dibuat untuk usaha perindustrian pallet tetapi bisa digunakan untuk pendirian usaha baru yang akan dibuat yakni pembuatan papan partikel (particle board) karena jenis usaha yang sama. Jadi CV. Riau Pallet tidak perlu mengubah surat-surat lainnya.

Dampak lingkungan akan muncul sehubungan dengan adanya pendirian setiap usaha tentu ada berdampak negatif, pada pembuatan papan partikel ini dampak lingkungan tidak dirasakan oleh lingkungan sekitar tetapi lebih kepada para pekerjanya, dampak yang ditimbulkan oleh resin kepada para pekerja tidak terlalu berbahaya. Hanya saja pekerja yang bekerja wajib menggunkan safety agar pekerja tidak terkena langsung dari bahayanya bahan kimia yang terkandung dalam resin atau epoxy. Begitu juga dengan bagian pengeringan serbuk kayu pekerja wajib menggunakan masker agar pekerja tidak langsung menghirup debu-debu yang dihasilkan oleh serbuk kayu tersebut.

Berdasarkan analisis aspek legal dan lingkungan, usaha papan partikel ini dinyatakan layak karena adanya badan hukum, surat-surat untuk legalisasi kegiatan bisnis dan adanya keamanan untuk para pekerja dari limbah yang dihasilkan oleh kegiatan perusahaan.

\section{Aspek MSDM}

Pada aspek manajemen sumber daya manusia dibutuhkan data tentang spesifikasi pekerja yang dibutuhkan untuk karyawan yang akan bekerja ditempat pembuatan papan partikel di CV. Riau Pallet. Namun sebelum menentukan kapasitas karyawan yang dibutuhkan, sebuah perusahaan perlu menentukan struktur organisasi terlebih dahulu karena strukur organisasi memiliki peranan penting dalam mengatur segala sesuatu yang akan dijalankan oleh pemilik usaha sesuai dengan kebijakannya.

Perencanaan tenaga kerja dilakukan dengan menganalisis jumlah tenaga kerja berdasarkan deskripsi pekerjaan dan spesifikasi pekerjaan sehingga perusahaan bisa mendapatkan tenaga kerja dengan kuantitas dan kualitas yang sesuai. Berikut merupakan kebutuhan spekerja.

Tabel 4.22 Kebutuhan Pekerja

\begin{tabular}{|l|l|}
\hline \multicolumn{1}{|c|}{ Jabatan } & Jumlah \\
\hline Quality Control & 2 \\
\hline Operator produksi & 6 \\
\hline Pengawas gudang & 1 \\
\hline
\end{tabular}

(Sumber : Pengolahan Data, 2016) 

dalam Bidang Teknik Industri

\section{Aspek Finansial}

Perhitungan Perkiraan Pendapatan

Perkiraan pendapatan CV. Riau Pallet produksi particle board menggunakan perkiraan pendapatan harian yang diharapkan oleh pemilik perusahaan adalah sebagai berikut:

Perkiraan tahun ke 1 (pertama) $=\operatorname{Rp} 34.5000 .000,-\mathrm{x}$ 12 bulan $=\operatorname{Rp} 414.000 .000$,

Perkiraan tahun ke 2 (dua)=Rp 40.250.000,- x 12 bulan=Rp 483.000.000,-

Perkiraan tahun ke 3 (tiga)=Rp 42.550.000,- x 12 bulan=Rp 510.600.000,-

Perkiraan tahun ke 4 (empat)=Rp 46.000.000 x 12 bulan=Rp 552.000.000,-

\section{Perhitungan Perkiraan Biaya Operasional}

Berikut adalah perkiraan biaya operasional yang akan dikeluarkan oleh CV. Riau Pallet produksi particle board tiap tahunnya:

Tabel 4.23 Rekapitulasi Perkiraan Biaya Operasional Tahun ke 1

\begin{tabular}{|c|l|r|}
\hline No. & \multicolumn{1}{|c|}{ Item } & \multicolumn{1}{c|}{ Biaya (Rp) } \\
\hline 1 & Bahan baku resin & $70.570 .000,-$ \\
\hline 2 & Gaji karyawan & $155.520 .000,-$ \\
\hline 3 & THR Karyawan & $9.000 .000,-$ \\
\hline 4 & Biaya pemasaran & $4.000 .000,-$ \\
\hline 5 & Beban telepon dan wifi & $800.000,-$ \\
\hline 6 & Listrik & $6.000 .000,-$ \\
\hline 7 & BBM genset & $1.800 .000,-$ \\
\hline \multicolumn{2}{|c|}{ Total } & $247.690 .000,-$ \\
\hline
\end{tabular}

(Sumber : Pengolahan Data, 2016)

Tabel 4.24 Rekapitulasi Perkiraan Biaya

Operasional Tahun ke 2

\begin{tabular}{|c|l|r|}
\hline No. & \multicolumn{1}{|c|}{ Item } & \multicolumn{1}{c|}{ Biaya (Rp) } \\
\hline 1 & Bahan baku resin & $80.570 .000,-$ \\
\hline 2 & Gaji karyawan & $155.520 .000,-$ \\
\hline 3 & THR Karyawan & $9.000 .000,-$ \\
\hline 4 & Biaya pemasaran & $4.000 .000,-$ \\
\hline 5 & Beban telepon dan wifi & $800.000,-$ \\
\hline 6 & Listrik & $6.000 .000,-$ \\
\hline 7 & BBM genset & $1.800 .000,-$ \\
\hline \multicolumn{2}{|c|}{ Total } & $257.690 .000,-$ \\
\hline
\end{tabular}

(Sumber : Pengolahan Data, 2016)

Tabel 4.25 Rekapitulasi Perkiraan Biaya Operasional Tahun ke 3

\begin{tabular}{|c|l|r|}
\hline No. & \multicolumn{1}{|c|}{ Item } & \multicolumn{1}{c|}{ Biaya (Rp) } \\
\hline 1 & Bahan baku resin & $90.570 .000,-$ \\
\hline 2 & Gaji karyawan & $155.520 .000,-$ \\
\hline 3 & THR Karyawan & $9.000 .000,-$ \\
\hline 4 & Biaya pemasaran & $4.000 .000,-$ \\
\hline 5 & Beban telepon dan wifi & $800.000,-$ \\
\hline
\end{tabular}

\begin{tabular}{|c|l|r|}
\hline 6 & Listrik & $6.000 .000,-$ \\
\hline 7 & BBM genset & $1.800 .000,-$ \\
\hline \multicolumn{2}{|c|}{ Total } & $267.690 .000,-$ \\
\hline
\end{tabular}

(Sumber : Pengolahan Data, 2016)

Tabel 4.26 Rekapitulasi Perkiraan Biaya

Operasional Tahun ke 4

\begin{tabular}{|c|l|r|}
\hline No. & \multicolumn{1}{|c|}{ Item } & \multicolumn{1}{c|}{ Biaya (Rp) } \\
\hline 1 & Bahan baku resin & $110.570 .000,-$ \\
\hline 2 & Gaji karyawan & $155.520 .000,-$ \\
\hline 3 & THR Karyawan & $9.000 .000,-$ \\
\hline 4 & Biaya pemasaran & $4.000 .000,-$ \\
\hline 5 & Beban telepon dan wifi & $800.000,-$ \\
\hline 6 & Listrik & $6.000 .000,-$ \\
\hline 7 & BBM genset & $1.800 .000,-$ \\
\hline \multicolumn{2}{|c|}{ Total } & $287.690 .000,-$ \\
\hline
\end{tabular}

(Sumber : Pengolahan Data, 2016)

\section{Biaya Depresiasi (Penyusutan)}

Dalam setiap melakukan investasi, maka terdapat biaya depresiasi dari peralatan atau aset yang digunakan karena waktu dan pemakaian. Berikut ini merupakan daftar asset yang memiliki depresiasi. Untuk menghitung depresiasi ini dengan menggunakan metode garis lurus (stright line method). Pemyusutan selama 4 tahun sesuai rumus (2.4) sebagai berikut:

$$
\begin{aligned}
& \text { Penyusutan }=\frac{\text { investasi-residu }}{\text { umur ekonomis }} \\
& \text { Penyusutan }=\frac{\text { investasi-residu }}{\text { umur ekonomis }}=\frac{548.850 .000-162.550 .000}{4}
\end{aligned}
$$$$
=\text { Rp. 96.575.000,- }
$$

\section{Minimum Attractive Rate of Return MARR}

MARR merupakan tingkat bunga yang dipakai sebagai patokan dasar dalam mengevaluasi dan membandingkan berbagai alternatif. Berikut rumus MARR.

$$
\operatorname{MARR}=i+\alpha+\text { ekspektasi laba }
$$

Dimana :

$\mathrm{i}=$ bunga deposito bank; 7,1\% pada bulan April 2016 pertahunnya (Bank BRI)

$\alpha=$ high risk return (persen resiko pengembalian); $0 \%$ (karena tempat pembuatan papan partikel belum ada di wilayah Panam)

Ekspektasi laba $=0 \%$ (karena modal berasal dari modal sendiri)

MARR $=7,1 \%+0 \%$

$\operatorname{MARR}=7,1 \%$

\section{Net Present Value (NPV)}

NPV merupakan formula untuk menghitung nilai bersih pada waktu sekarang. Formula ini digunakan berdasarkan selisih antara investasi dengan PV kas bersih. Maka, perhitungan PV kas bersih invetasi dari tahun ke I-IV adalah: NPV=Total PV Kas Bersih - Total PV Investasi 
$\mathrm{NPV}=\mathrm{Rp} 1.135 .401 .152,--\mathrm{Rp} 548.850 .000,-$ $\mathrm{NPV}=\mathrm{Rp} 586.551 .152,-$

\section{Internal Rate of Return (IRR)}

IRR merupakan formula untuk menunjukkan berapa \% pengembalian investasi tiap tahunnya. Perhitungannya adalah sebagai berikut:

Berdasarkan perhitungan di atas, maka:

$\mathrm{IRR}=\mathrm{i}_{1}+\left(\frac{\mathrm{NPV}_{1}}{\mathrm{NPV}_{1}-\mathrm{NPV}_{2}}\right) \cdot\left(\mathrm{i}_{2}-\mathrm{i}_{1}\right)$

$\mathrm{IRR}=$

$$
\begin{aligned}
& 0,071+\left(\frac{586.551 .152}{586.551 .152-55.624 .136}\right) \cdot(0,4-0,071) \\
& I R R=0,071+1,00 \times 0,329 \\
& I R R=0,4=40 \% \\
& I R R>\text { MARR }=40 \%>7,1 \%
\end{aligned}
$$

\section{Payback Periode (PP)}

PP merupakan formula untuk mengetahui berapa lama waktu pengembalian modal. Bila waktu pengembalian modal lebih kecil dari pada waktu umur ekonomis, maka investasi tidak layak. Perhitungannya adalah sebagai berikut:

Tabel 4.31 Perhitungan Payback Periode (PP)

\begin{tabular}{|c|c|c|}
\hline Tahun & $\begin{array}{c}\text { Kas Bersih } \\
\text { (Rp) }\end{array}$ & $\begin{array}{c}\text { Kumulatif } \\
\text { Kas Bersih } \\
\text { (Rp) }\end{array}$ \\
\hline 1 & $268.403 .361,-$ & $268.403 .361,-$ \\
\hline 2 & $296.031 .267,-$ & $564.434 .628,-$ \\
\hline 3 & $288.486 .371,-$ & $852.920 .999,-$ \\
\hline 4 & $282.480 .153,-$ & $1.135 .401 .152,-$ \\
\hline
\end{tabular}

(Sumber: Pengolahan Data, 2016)

Berdasarkan perhitungan di atas, maka:

$\mathrm{PP}=\left[\mathrm{n}+\left(\frac{\mathrm{a}-\mathrm{b}}{\mathrm{c}-\mathrm{b}}\right)\right] \cdot 12$

$\mathrm{PP}=\left[1+\left(\frac{548.850 .000-268.403 .361}{564.434 .628-268.403 .361}\right)\right] .12$

$\mathrm{PP}=12,9 \approx 1$ tahun 1 bulan

Jadi, pengembalian modal pada investasi adalah selama 1 tahun 1 bulan.

\section{Kesimpulan}

Berdasarkan tujuan penelitian yang telah ditetapkan, maka diperoleh kesimpulan yaitu berdasarkan aspek pemasaran usaha particle board sebagai pemanfaatan limbah kayu di CV. Riau Pallet, didapat dari pengolahan data kuisioner yang telah disebar ke 27 orang pemilik toko Perabot di kota Pekanbaru. Para responden yang didominasi dengan laki-laki dan di atas umur 25 tahun ini diperoleh tingkat persetujuan terhadap 13 pernyataan yang diberikan berada di atas $67 \%$ yang berarti pernyataan-pernayataan yang diberikan kepada setiap responden, responden menyetujuinya.

Dilihat dari aspek teknis, kebutuhan bahan baku utama yang digunakan untuk pembuatan particle board ini adalah serbuk kayu yang dihasilkan dari sisa penggergajian pada proses pembuatan pallet yang ada pada CV. Riau Pallet itu sendiri. Sisa serbuk kayu yang dihasilkan rata-rata 21,52 $\mathrm{m}^{3}$ perbulan setiap tahunnya dapat mengahasilkan rata-rata 470 lembar papan berukuran $122 \times 224 \times 1,8 \mathrm{~cm}$ (ukuran standar perabot).

Beradarkan aspek legal dan lingkungan, pihak CV. Riau Pallet tidak perlu mengubah surat atau membuat surat-surat kelegalan baru karena masih bisa digunakan surat-surat kelegalan untuk produksi pallet, karena jenis usaha yang tertera pada surat kelegalan tersebut sama. Begitu juga dengan lingkungan, jika para pekerja dapat bekerja dengan memperhatikan kesehatan dan keselamatan kerja maka usaha ini dapat dilakukan.

Aspek manajemen sumber daya manusia apabila ditinjau, pada pembuatan usaha particle board ini membutuhkan 9 orang tenaga kerja yang tidak membutuhkan pendidikan formal atau pengetahuan khusus hanya saja dibuthkan keterampilan dan ketekunan dalam bekerja.

Aspek finansial, rencana kebutuhan investasi yang dibutuhkan untuk pembuatan usaha ini adalah Rp. 548.850.000,- dengan biaya penyusutan sebesar Rp. 96.575.000,- dan umur ekonomis usaha ini diperkiran sekitar 4 tahun, maka didapat nilai NPV sebesar Rp 586.551.152,- dengan tingkat suku bunga $7,1 \%$ yang memiliki nilai positif maka usaha papan partikel ini layak dan menguntungkan jika dikembangkan oleh CV. Riau Pallet. Tingkat IRR yang dicapai dalam periode 4 tahun adalah $40 \%$ dimana nilai tersebut lebih besar dari nilai MARR yang ditetapkan oleh pihak perusahaan yaitu 7,1\%. Payback Period merupakan metode yang digunakan untuk menghitung lama periode yang diperlukan untuk mengembalikan uang yang telah diinvestasikan dari aliran kas masuk (proceeds) tahunan yang dihasilkan oleh proyek investasi tersebut. Lama periode yang diperlukan untuk mengembalikan uang yang telah diinvestasikan adalah 1 tahun 1 bulan. Hal ini menunjukkan usaha ini layak untuk di kembangkan karena dalam waktu 1 tahun telah dapat mengembalikan modal yang di investasikan.

\section{Daftar Pustaka}

Aditya, A.S. Analisis Kelayakan Usaha Lemari Rak Simpe and Easy Delivery di Kecamatan Cikarang*. Jurnal. Jurusan Teknik Industri. Institut Teknologi Nasional. Bandung. 2014.

Aningrum, W.W Analisis Kelayakan Investasi Pembukaan Cabang Baru Rumah Makan Soto Banjar Nyaman Banar di Kabupaten Kutai Kartanegara. Jurnal. Jurusan Ilmu 
Administrasi Bisnis. Universitas Mulawarman. 2015.

Arikunto, S. Prosedur Penelitian: Suatu Pengantar Praktik. Penerbit Rineka Cipta, Jakarta. 2006.

Fahmi, I. Studi Kelayakan Bisnis dan Keputusan Investasi. Edisi Pertama, Mitra Wacana Media, Jakarta, 2014 